\title{
Correlation of Total Lymphocyte Count with CD4 Count in HIV/AIDS Patients
}

\author{
Ardo Sanjaya $^{1}$, Christine Sugiarto ${ }^{2}$, Ronald Jonathan ${ }^{3}$ \\ ${ }^{1}$ Faculty of Medicine, Maranatha Christian University \\ ${ }^{2}$ Department of Clinical Pathology Maranatha Christian University \\ Jl. Prof. Drg. Surya Sumantri MPH No. 65 Bandung 40164 Indonesia \\ ${ }^{3}$ HIV/AIDS, IMAI-HIV/AIDS, WHO Consultant team \\ Email: christine_roys@yahoo.com
}

\begin{abstract}
$H I V$ infection is a chronic infection of the immune system with a target of CD4 cells. Total lymphocyte count (TLC) can be done in resource-limited areas and are able to be used as a substitute to CD4 count. An increase in CD8 count can disturb the correlation between CD4 and TLC especially during the late clinical stage.Objective of this research is to find out the correlation of total lymphocyte count with CD4 count and to find out the influence of the clinical staging on the correlation of total lymphocyte count and CD4 count.This study is an observational, analytical and cross sectional study using the medical records of Klinik Teratai RSHS Bandung. The data is sorted according to the WHO clinical staging and are analyzed using Pearson's correlation and Fisher's transformation with $\alpha=0.05$. The results showed that TLC have a correlation with CD4 count in all stadiums $(r: 0,501-0,684, p<0,01)$. There is no significant difference of the correlation coefficients between the clinical stages ( $p>0.05)$. There is a correlation between TLC and CD4 count on HIV infected patients and there is no significant decrease of correlation of TLC and CD4 count on HIV infected patients with worsening of the WHO clinical stages.
\end{abstract}

Keywords: CD4 count, total lymphocyte count, HIV/AIDS 


\title{
Korelasi antara Jumlah Limfosit Total dan Jumlah CD4 pada Pasien HIV/AIDS
}

\author{
Ardo Sanjaya $^{1}$, Christine Sugiarto ${ }^{2}$, Ronald Jonathan ${ }^{3}$ \\ ${ }^{1}$ Fakultas Kedokteran, Universitas Kristen Maranatha \\ ${ }^{2}$ Bagian Patologi Klinik, Universitas Kristen Maranatha \\ Jl. Prof. Drg. Surya Sumantri MPH No. 65 Bandung 40164 Indonesia \\ ${ }^{3}$ Tim Konsultan HIV/AIDS, IMAI-HIV/AIDS WHO \\ Email: christine_roys@yahoo.com
}

\begin{abstract}
Abstrak
Infeksi HIV adalah infeksi kronik dari sistem imun dengan target sel CD4. Sel CD4 berkurang jumlahnya sehingga pemeriksaan jumlah CD4 digunakan untuk memulai terapi dan memantau progresi penyakit. Pemeriksaan jumlah limfosit total (JLT) dapat dilakukan pada daerah fasilitas terbatas sehingga dapat berguna sebagai pengganti jumlah CD4. Peningkatan jumlah CD8 dapat mengganggu korelasi jumlah CD4 terhadap jumlah limfosit total terutama pada stadium klinis lanjut. Tujuan penelitian untuk mengetahui korelasi JLT dengan jumlah CD4 pada pasien terinfeksi HIV dan mengetahui pengaruh stadium klinis terhadap korelasi JLT dan jumlah CD4. Penelitian ini bersifat observasional analitik dengan rancangan cross-sectional menggunakan data rekam medis dari Klinik Teratai RSHS Bandung. Data dibagi perstadium klinis WHO kemudian dianalisis menggunakan korelasi Pearson dan Fisher dengan nilai $\alpha=0,05$. Hasil penelitian menunjukkan JLT mempunyai korelasi sedang dengan jumlah CD4 pada semua stadium ( $\mathrm{r}$ berkisar antara 0,501-0,684 dan $\mathrm{p}<0,01$ ). Tidak ditemukan perbedaan bermakna dari koefisien korelasi antar stadium klinis infeksi HIV $(p>0,05)$. Terdapat korelasi yang baik antara JLT dan jumlah CD4 pada pasien terinfeksi HIV dan tidak terdapat penurunan korelasi antara JLT dengan jumlah CD4 pasien terinfeksi HIV dengan semakin beratnya stadium klinis menurut WHO.
\end{abstract}

Kata kunci: jumlah CD4, jumlah limfosit total, HIV/AIDS 


\section{Pendahuluan}

Penyakit human immunodeficiency virus/ acquired immunodeficiency syndrome (HIV/AIDS) disebabkan oleh infeksi HIV. HIV adalah suatu retrovirus yang berasal dari famili retroviridae genus lentivirus dan terdiri atas dua tipe utama pada manusia yaitu HIV-1 dan HIV2. ${ }^{1}$ Infeksi HIV yang banyak terjadi di negara berkembang mendorong suatu kebutuhan pemeriksaan laboratorium yang murah dan terjangkau. Direktorat Jenderal Penanggulangan Penyakit dan Penyehatan Lingkungan Kementrian Kesehatan Indonesia melaporkan bahwa sampai Desember 2012 terdapat 42.887 orang menderita AIDS dan 98.390 orang terinfeksi HIV dengan prevalensi tertinggi pada daerah Papua. ${ }^{2}$

Target utama dari infeksi HIV adalah melalui sel CD4. Sel ini secara selektif berkurang jumlahnya baik akibat efek langsung dari virus ataupun reaksi imun dari tubuh. ${ }^{3}$ Infeksi HIV mengakibatkan aktivasi kronik dari sistem imun yang mengakibatkan disfungsi dari sistem imun. Aktivasi sistem imun ini dilihat salah satunya dari peningkatan proliferasi limfosit $\mathrm{T}$, tetapi dari proliferasi limfosit $\mathrm{T}$ tersebut ditemukan terjadinya penurunan jumlah $\mathrm{CD} 4$ dan peningkatan jumlah CD8. ${ }^{4}$

Berkurangnya sel CD4 mengakibatkan berkurangnya jumlah limfosit total (JLT) seperti yang dibuktikan oleh Alavi et al. bahwa JLT dapat digunakan sebagai pemeriksaan pengganti jumlah CD4 dalam pemantauan infeksi HIV. ${ }^{5}$ Penelitian Ray et al. memperlihatkan bahwa terdapat peningkatan jumlah CD8 hampir dua kali lipat pada pasien terinfeksi HIV dibandingkan kontrol orang HIV negatif. ${ }^{6}$ Beberapa hasil penelitian menyebutkan hasil korelasi yang berbeda antara jumlah CD4 dan JLT dari korelasi baik hingga ke lemah. ${ }^{7,8}$ Beberapa penelitian juga menyebutkan terjadi peningkatan jumlah CD8 pada pasien terinfeksi HIV, sedangkan JLT dipengaruhi oleh jumlah CD4 dan jumlah CD8, peningkatan jumlah CD8 dapat mengaburkan penurunan jumlah CD4. ${ }^{6,10}$

Tujuan penelitian adalah mengetahui korelasi JLT dengan jumlah CD4 pada pasien HIV/AIDS dan mengetahui pengaruh stadium klinis terhadap korelasi JLT dan jumlah CD4 pada pasien HIV/AIDS.

\section{Metode}

Penelitian ini merupakan penelitian observasional analitik dengan rancangan crosssectional menggunakan data rekam medis dari Klinik Teratai Rumah Sakit Dr. Hasan Sadikin di Bandung. Sampel penelitian merupakan hasil pemeriksaan laboratorium dari spesimen darah pasien terinfeksi HIV yang datang ke Klinik Teratai Rumah Sakit Dr. Hasan Sadikin Bandung 


\section{Research Article}

dari bulan Maret 2007 sampai dengan Agustus 2009 dengan hasil tes HIV positif dan belum memulai terapi antiretroviral.

Data dibagi berdasarkan stadium klinis WHO menjadi 4 kelompok, masing-masing untuk stadium klinis 1, 2, 3, dan 4. ${ }^{11}$ Data pada tiap kelompok dianalisis menggunakan analisis korelasi Pearson untuk melihat Pearson's product-moment correlation coefficient tiap kelompok. Koefisien korelasi tiap kelompok dibandingkan menggunakan Fisher's r-to-z transformation untuk melihat perbedaan korelasi antar kelompok. Interpretasi untuk nilai koefisien korelasi ditampilkan pada Tabel 1.

Pada penelitian dihitung persentase pasien yang tidak mendapat terapi antiretroviral karena JLT $\geq 1.200 \mathrm{sel} / \mathrm{mm}^{3}$, padahal jumlah CD4 $<200 \mathrm{sel} / \mathrm{mm}^{3}$ untuk menilai apakah perhitungan jumlah JLT cukup baik untuk menjadi patokan memulai terapi.

Tabel 1 Skala Korelasi Penelitian

\begin{tabular}{cc}
\hline Koefisien Korelasi & Interpretasi \\
$0-0,20$ & Korelasi Sangat Lemah \\
$0,20-0,40$ & Korelasi Lemah \\
$0,40-0,70$ & Korelasi Sedang \\
$0,70-0,90$ & Korelasi Kuat \\
$0,90-1,00$ & Korelasi Sangat Kuat \\
\hline
\end{tabular}

\section{Hasil}

Antara tanggal 13 Agustus 2007 sampai dengan tanggal 31 Maret 2009 diperoleh 931 subjek penelitian. Subjek yang memenuhi syarat penelitian ini berjumlah 350 orang yang dibagi dalam 4 stadium klinis. Stadium 1 sebanyak 106 subjek, stadium 2 sebanyak 23 subjek, stadium 3 sebanyak 89 subjek, dan stadium 4 sebanyak 132 subjek.

Pada penelitian ini dilakukan pemeriksaan JLT dan jumlah CD4, serta penentuan stadium klinis tiap subjek penelitian. Analisis statistik dilakukan untuk menentukan korelasi antara JLT dengan jumlah CD4 pada keseluruhan subjek penelitian dan setelah dibagi perstadium klinis. Korelasi dinilai menggunakan korelasi Pearson sedangkan perbandingan antar korelasi dinilai menggunakan Fisher's Z- Transformation. Korelasi antara JLT dengan jumlah CD4 dapat dilihat pada Tabel 2.

Pada stadium 1, JLT memiliki korelasi yang sedang dan secara statistik sangat signifikan dengan jumlah CD4 ( $\mathrm{r}=0,665$ dan $\mathrm{p}<0,01)$. Pada stadium 2, JLT memiliki korelasi yang sedang dan secara statistik sangat signifikan dengan jumlah CD4 ( $r=0,651$ dan $\mathrm{p}<0,01)$. 
Pada stadium 3, JLT memiliki korelasi yang sedang dan secara statistik sangat signifikan dengan jumlah CD4 ( $\mathrm{r}=0,684$ dan $\mathrm{p}<0,01)$. Pada stadium 4, JLT memiliki korelasi sedang dan secara statistik sangat signifikan dengan jumlah CD4 $(r=0,501$ dan $\mathrm{p}<0,01)$.

Pada Tabel 3 terlihat bahwa korelasi antara JLT dengan jumlah CD4 perstadium klinis mengalami penurunan terutama pada stadium 4 walaupun secara statistik perbedaan tersebut tidak signifikan.

Tabel 4 memperlihatkan koefisien determinasi antara JLT dengan jumlah CD4. Pada stadium 1 didapat $\mathrm{R}^{2}=0,442(44,2 \%)$, stadium 2 didapat $\mathrm{R}^{2}=0,424(42,4 \%)$, stadium 3 didapat $\mathrm{R}^{2}=0,468(46,8 \%)$, dan pada stadium 4 didapat $\mathrm{R}^{2}=0,251(25,1 \%)$.

Gambar 1 memperlihatkan persentase pasien yang harus mulai terapi namun tidak mendapat terapi yaitu 22\% (76 pasien) dari keseluruhan subjek.

Tabel 2 Korelasi antara JTL dengan Jumlah CD4 pada Subjek Penelitian

\begin{tabular}{cccccccc}
\hline \multicolumn{2}{c}{ Stadium 1} & \multicolumn{2}{c}{ Stadium 2} & \multicolumn{2}{c}{ Stadium 3} & \multicolumn{2}{c}{ Stadium 4} \\
$\mathrm{r}$ & $\mathrm{p}$ & $\mathrm{r}$ & $\mathrm{p}$ & $\mathrm{r}$ & $\mathrm{p}$ & $\mathrm{r}$ & $\mathrm{p}$ \\
0,665 & $<0,01$ & 0,651 & $<0,01$ & 0,684 & $<0,01$ & 0,501 & $<0,01$ \\
\hline
\end{tabular}

Tabel 3 Perbandingan Korelasi antara JTL dengan Jumlah CD4 Perstadium Klinis

\begin{tabular}{lllllcr}
\hline & Stadium 1 & Stadium 2 & Stadium 3 & Stadium 4 & $\begin{array}{l}\text { One-tailed } p \\
\text { value }\end{array}$ \\
$\mathrm{n}$ & 106 & 23 & 89 & 132 & $\mathrm{p}>0,05$ \\
$\mathrm{r}$ & 0,665 & 0,651 & 0,684 & 0,501 & $\mathrm{p}$ \\
\hline
\end{tabular}

Tabel 4 Koefisien Determinasi dari Korelasi JLT dengan Jumlah CD4

\begin{tabular}{ccccc}
\hline & Stadium & Stadium & Stadium & Stadium \\
$\mathrm{r}^{2}$ & 1 & 2 & 3 & 4 \\
\hline
\end{tabular}




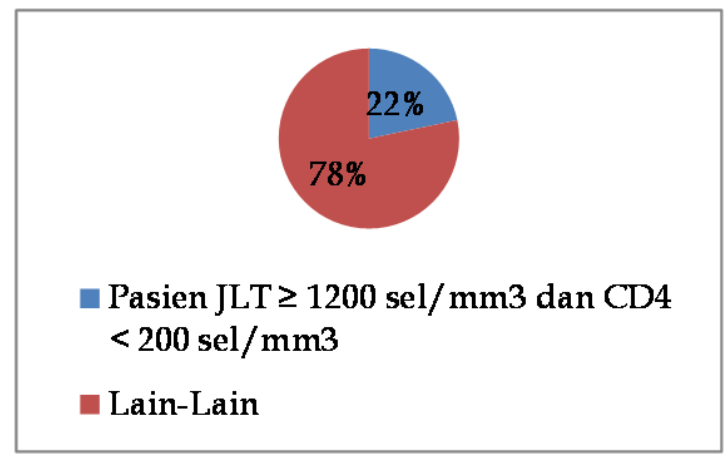

\section{Gambar 1 Persentase Subjek Penelitian yang Tepat Memulai Terapi dan Tidak Mendapat Terapi}

\section{Diskusi}

Pada Tabel 2 terlihat bahwa terdapat korelasi yang baik dan secara statistik signifikan antara JLT dengan jumlah CD4 pada seluruh stadium infeksi HIV. Hal ini menunjukkan bahwa penurunan jumlah CD4 juga diikuti oleh penurunan JLT.

CD4 merupakan salah satu bagian dari limfosit T. Limfosit terdiri atas dua subtipe yaitu limfosit B yang merupakan sel primer dari sistem pertahanan humoral dan limfosit $\mathrm{T}$ yang merupakan sel primer dari sistem pertahanan seluler. Limfosit terdiri atas 3\%-21\% sel B dan $20 \%-80 \%$ sel T. Sel T terdiri atas 34\%-67\% sel CD4 dan 10\%-42\% sel CD8. ${ }^{13}$ Mekanisme berkurangnya sel CD4 pada pasien terinfeksi HIV dapat dibagi menjadi tiga kategori umum yaitu efek langsung dari replikasi virus, efek tidak langsung, dan efek sistemik virus pada turnover selular. Efek langsung terjadi karena HIV menginfeksi sel CD4 yang teraktivasi, sel yang terinfeksi ini dapat mati akibat efek sitopatik langsung dari HIV atau akibat respons sel sitotoksik (CD8) terhadap sel yang terinfeksi. Efek tidak langsung HIV dalam mengurangi jumlah sel CD4 disebut juga sebagai bystander effect. Efek sistemik virus terutama ditemukan pada turnover sel T. Pada sel $\mathrm{T}$ didapatkan peningkatan proliferasi dari sel diikuti dengan peningkatan kematian sel. ${ }^{1}$

Tabel 3 menunjukkan bahwa perbedaan korelasi antar stadium tidak bermakna secara statistik ( $p>0,05)$. Data ini menunjukkan bahwa seiring berjalannya penyakit, korelasi JLT dengan jumlah CD4 mengalami penurunan tetapi perbedaan korelasi antar stadium secara statistik tidak bermakna. Hal ini dapat dijelaskan dari penelitian Ray et al. yang menyatakan bahwa peningkatan CD8 telah terjadi dari stadium awal (asimptomatik) dari infeksi HIV 


\section{Research Article}

sehingga dengan semakin beratnya stadium klinis faktor yang paling berpengaruh hanya penurunan jumlah CD4. ${ }^{6}$

Tabel 4 menunjukkan koefisien determinasi dari korelasi JLT dengan jumlah CD4 pada penelitian ini. Koefisien determinasi adalah persentase dari variasi nilai variabel dependen yang dapat dijelaskan oleh variasi dari nilai variabel independen. Dalam penelitian ini koefisien determinasi menunjukkan persentase dari variasi nilai jumlah CD4 yang dapat dijelaskan oleh variasi dari nilai JLT. Pada stadium 1 didapatkan bahwa 44,2\% variasi jumlah CD4 dapat dijelaskan oleh variasi dari JLT, stadium 2 didapatkan bahwa 42,4\% variasi jumlah CD4 dapat dijelaskan oleh variasi dari JLT, stadium 3 didapatkan bahwa 46,8\% variasi jumlah CD4 dapat dijelaskan oleh JLT, sedangkan pada stadium 4 hanya 25,1\% dari variabel CD4 yang dapat dijelaskan oleh JLT. Hasil ini menunjukkan bahwa walaupun koefisien korelasi dari JLT dengan jumlah CD4 sedang, didapatkan korelasi tersebut hanya dapat menjelaskan kurang dari 50\% data. Penggunaan JLT sebagai pengganti jumlah CD4 tidak dianjurkan karena besar kemungkinan adanya pasien yang tidak mendapat terapi antiretroviral pada saat yang tepat.

Gambar 1 menunjukkan bahwa walaupun koefisien korelasi antara JLT dengan jumlah CD4 sedang pada seluruh subjek penelitian, 22\% subjek yang harus menerima terapi tidak mendapat terapi karena JLT $\geq 1.200 \mathrm{sel} / \mathrm{mm}^{3}$ walaupun CD4 $<200 \mathrm{sel} / \mathrm{mm}^{3}$. Panduan WHO untuk mulai terapi antiretroviral tanpa perhitungan CD4 adalah bila JLT $\geq 1.200 \mathrm{sel} / \mathrm{mm}^{3}$, sedangkan untuk mulai terapi adalah berdasarkan jumlah CD4 adalah $<200 \mathrm{sel} / \mathrm{mm}^{3}{ }^{3}{ }^{12}$ Hasil ini menunjukkan penggunaan JLT sebagai pengganti pemeriksaan CD4 melewatkan 22\% pasien HIV/AIDS dalam memulai terapi antiretroviral.

Walaupun ditemukan korelasi antara JLT dengan jumlah CD4, tetapi tidak menutup kemungkinan saat penggunaaan klinis pemeriksaan JLT untuk inisiasi terapi ada pasien yang terlambat menerima terapi. Pada penelitian ini ditemukan $22 \%$ pasien yang seharusnya memulai terapi, tidak menerima terapi. Penggunaan JLT sebagai pengganti pemeriksaan jumlah CD4 sudah tidak dianjurkan menurut panduan WHO tahun 2010, namun pada daerah fasilitas terbatas pemeriksaan JLT masih lebih mudah didapat daripada CD4. Penggunaan JLT sebagai pengganti CD4 juga harus diteliti lebih lanjut karena penelitian ini hanya membuktikan terdapat korelasi antara JLT dengan jumlah CD4, tetapi tidak membuktikan sensitivitas dan spesifisitas JLT dalam memprediksi jumlah CD4 pada pasien HIV/AIDS.

Dengan kemajuan teknologi penghitungan CD4, penggunaan pemeriksaan point-of-care dapat lebih menjangkau daerah dengan fasilitas terbatas dan dapat digunakan sebagai alternatif pemeriksaan bakumas jumlah CD4 menggunakan flow cytometry dan pengganti pemeriksaan JLT. 


\section{Research Article}

\section{Simpulan}

Terdapat korelasi antara JLT dengan jumlah CD4 pada pasien HIV/AIDS. Tidak terdapat penurunan korelasi secara bermakna antara JLT dengan jumlah CD4 pada pasien HIV/AIDS dengan semakin beratnya stadium klinis menurut WHO.

\section{Daftar Pustaka}

1. Holmes KK, Sparling PF, Stamm WE, Piot P, Wasserheit JN, Corey L, et al. Sexually transmitted disease. 4th ed. New York: The McGraw-Hills Companies; 2008.

2. Direktorat Jenderal Penanggulangan Penyakit dan Penyehatan Lingkungan Kementrian Kesehatan Indonesia. Statistik kasus HIV AIDS Indonesia. 2013 [cited 2013 July 5]. Available from: www.spiritia.or.id.

3. Goldman L, Schafer AI. Goldman's cecil medicine. 24th ed. Elsevier; 2012.

4. Catalfamo M, Di Mascio M, Hu Z, Srinivasula S, Thaker V, Adelsberger J, et al. HIV infection-associated immune activation occurs by two distinct pathways that differentially affect CD4 and CD8 T cells. Proc National Acad Sci. 2008;105(50):19851-6.

5. Alavi SM, Ahmadi F, Farhadi M. Correlation between total lymphocyte count, hemoglobin, hematocrit, and CD4 count in HIV/AIDS Patients. Acta Med Iran. 2009;47(1):1-4.

6. Ray K, Gupta S, Bala M, Muralidhar S, Kumar J. CD4/CD8 lymphocyte counts in healthy, HIV-positive individuals \& AIDS patients. Indian J Med Res. 2006;124(3):319.

7. Buseri FI, Mark D, Jeremiah ZA. Evaluation of absolute lymphocyte count as a surrogate marker for CD4+ cell count for the initiation of antiretroviral therapy (ART) in resource-limited settings. Int J Biomed Lab Sci (IJBLS). $2012 ; 1(1): 44-9$.

8. Akinola NO, Olasode O, Adediran IA, Onayemi O, Murainah A, Irinoye O, Elujoba AA, Durosinmi MA. The search for a predictor of CD4 cell count continues: total lymphocyte count is not a substitute for CD4 cell count in the management of HIV-infected individuals in a resource-limited setting. Clin Infect Dis. 2004;39(4):579-81. doi:10.1086/ 422722 .

9. Angelo ALD, Angelo CD, Torres AJL, Ramos AMC, Lima M, Netto EM, Brites C. Evaluating total lymphocyte counts as a substitute for $C D 4$ counts in the follow up of AIDS patients. Braz J Infect Dis. 2007;11(5):466-70.

10. Roederer M, Dubs JG, Anderson MT, Raju PA, Herzenberg LA. CD8 naive T cell counts decrease progressively in HIV-infected adults. J Clin Invest. 1995;95(5):2061-6.

11. WHO. Interim WHO clinical staging of HIV/AIDS and HIV/AIDS case definitions for surveillance. 2005 [cited 2013 March 5]. Available from: http://www.who.int/hiv/pub/guidelines/clinicalstaging.pdf?ua=1.

12. WHO. Regional office for South-East Asia. Laboratory guidelines for enumerating CD4 T lymphocytes in the context of HIV/AIDS. 2009 [cited 2013 March 5]. Available from: http://apps.searo.who.int/PDS_DOCS /B3180.pdf

13. Wilson DD. Manual of laboratory \& diagnostic tests. New York: The McGraw-Hill's Companies; 2008 